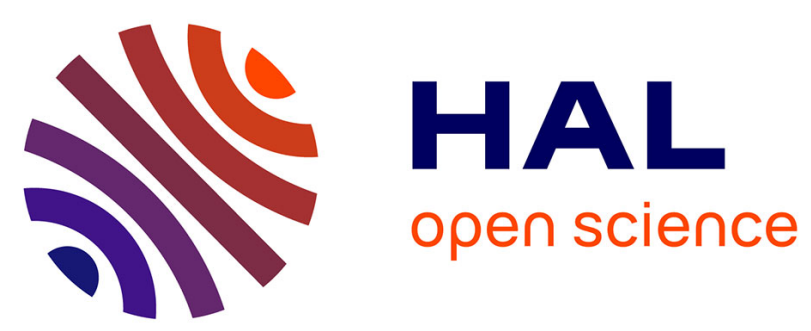

\title{
Bird communities of a temperate forest spatio-temporal partitioning between resident and migratory species
}

\author{
Lou Barbe, Regis Morel, Yann Rantier, Jean-Francois Lebas, Alain Butet
}

\section{To cite this version:}

Lou Barbe, Regis Morel, Yann Rantier, Jean-Francois Lebas, Alain Butet. Bird communities of a temperate forest spatio-temporal partitioning between resident and migratory species. Journal für Ornithologie $=$ Journal of Ornithology, 2018, 159 (2), pp.457-469. 10.1007/s10336-017-1523-y . hal01769648

HAL Id: hal-01769648

https://hal-univ-rennes1.archives-ouvertes.fr/hal-01769648

Submitted on 23 Oct 2018

HAL is a multi-disciplinary open access archive for the deposit and dissemination of scientific research documents, whether they are published or not. The documents may come from teaching and research institutions in France or abroad, or from public or private research centers.
L'archive ouverte pluridisciplinaire HAL, est destinée au dépôt et à la diffusion de documents scientifiques de niveau recherche, publiés ou non, émanant des établissements d'enseignement et de recherche français ou étrangers, des laboratoires publics ou privés. 


\section{Bird communities of a temperate forest: spatio-temporal partitioning between resident and migratory species}

Authors: Barbe, L. ${ }^{(1)}$ Morel, R. ${ }^{(2)}$, Rantier, Y. ${ }^{(1)}$, Lebas, J.F. ${ }^{(3)}$ and Butet, A. ${ }^{(1)}$

${ }^{(1)}$ UMR CNRS 6553 ECOBIO, Université de Rennes 1 - OSUR

Avenue du Gal Leclerc, 35042 Rennes cedex, France

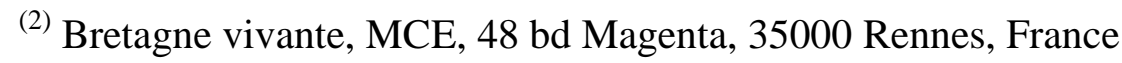

(3) Département d'Ille-et-Vilaine, Service Espaces Naturels, 1, avenue de la Préfecture, CS 24218, 35042 Rennes Cedex, France

Corresponding author: Lou Barbe - lou.barbe@univ-rennes1.fr

UMR CNRS 6553 ECOBIO, Université de Rennes 1 - OSUR

Avenue du Gal Leclerc, 35042 Rennes cedex, France

\section{ACKNOWLEDGEMENTS}

This study was financially supported by the Conseil Départemental d'Ille-et-Vilaine and was carried out in the protected sensitive natural area of the "Forêt de la Corbière". We thank Sébastien Gervaise (LPO 35), Philippe Briand, Sébastien Painchaud (CD 35) and Emmanuel Chabot, Pierre-Yves Pasco, Geoffrey Vigour, Claire Delanoë, Nathalie Dewynter (Bretagne Vivante) for their field assistance during the three years of bird surveys. We are very grateful to Lucy Alford who reviewed and improved the English of the manuscript. We acknowledge the three anonymous referees for previous reviews and their constructive comments on the paper. This paper is a contribution to the research team UMR CNRS 6553 Ecobio and the research consortium OSUR, Rennes. 


\section{ABSTRACT}

A lot of bird species are declining in Europe and studies of bird community assembly are fundamental to propose efficient conservation actions. Many studies were carried out on the regional variability of abundance and distribution of bird communities, but few studies considered the local patch variability. In this study, we worked on intra-patch variability of breeding bird community in the forest patch of Corbière (Britanny, France). We tested whether bird community distribution was related to habitat characteristics and whether distribution patterns depended on life history traits of species. During three years, we used a regular sampling and the point count method to sample whole bird community within this forest patch. Our results showed that several biotic and abiotic variables - distance to forest edge, deciduous tree cover, coppice cover, elevation - controlled individual abundances of bird species as well as indicators of bird community - abundance, diversity, evenness. Moreover, we found that abundances of resident birds, short-distance migrants and longdistance migrants were differently related to biotic and abiotic variables, and that these relationships varied within the breeding season. We suggest that this space partitioning may be explained by the temporal dynamics of the bird community: resident and short-distance species were present earlier than long-distance species in the forest patch, and might preferentially choose high quality habitats. Long-distance migrants arrived later in the breeding season and might not find the same habitat availability, they might consequently only nest close to the forest edge, in high sites or sites with sparse understory. Our results show that local studies, taking into account migratory status and species dynamics at intraseason scale, are important keys to understand distribution patterns which are observed along entire breeding seasons.

Keywords: forest biodiversity, bird community, species partitioning, migratory status, temporal dynamics 


\section{INTRODUCTION}

The study of bird communities is often used to determine indicators of health of natural habitats under global changes (Canterbury et al. 2000, Gregory et al. 2007). Specifically, studies of bird communities permit identification of population trends: for instance, Gregory et al. (2007) found a sharp decline (-13 \% over the period 1990-2002) of forest birds in Western Europe. Population trends may depend on life history traits of species: Julliard et al. (2003) and Jiguet et al. (2007) showed, noteworthy, the decline of specialist species - in France, this decline is moderate in protected areas but is accentuated in areas without special status (Devictor et al. 2007). Moreover, it has been shown that among European forest birds, long-distance migrants declined more strongly than short-distance migrants or permanent residents (Sanderson et al. 2006, Gregory et al. 2007). Arrival dates of migratory birds became earlier in recent decades, in particular for early migratory species (Tryjanowski et al. 2005), as did the starting dates for fall migration of long-distance migrants (Jenni \& Kéry 2003) and broods production (Both \& Visser 2001). Overall, global changes have strong effects on bird communities, and these effects depend on ecology and life history traits of bird species, especially their breeding phenology. As efficient practices of protection and conservation became crucial for maintaining avian biodiversity, we need to understand the mechanisms driving local bird abundance and distribution (Raymond et al. 2010, Balestrieri et al. 2015). According to studies at regional scales, forest bird communities can be driven by deterministic or random processes (Renner et al. 2014) and many studies were already conducted at this scale to identify deterministic processes, i.e. biotic and abiotic factors governing distribution of forest bird communities, such as forest composition and structure, and amount and nature of forest edges (Martin-Morales 2005, Goetz et al. 2010).

First, tree species composition and structure of forest patch drive bird community distribution. The density and age of trees can determine community species richness (James \& Warner 
1982, Berg 1997, Poulsen 2002). Spatial heterogeneity of tree species distribution may increase overall bird abundance and increase abundance of specific functional groups (Freemark \& Merriam 1986). Moreover, the composition of forest stands - deciduous vs coniferous dominance - is a very important factor in habitat selection by species, since many species have distinct habitat and resource preferences (James \& Wamer 1982, Patterson \& Best 1996, Berg 1997). More recent studies also showed that heterogeneity of vertical structure and height of canopy can increase the richness of migratory birds (Goetz et al. 2007, 2010). Finally, available resources, often related to moisture in forest habitats due to tree density (Petit et al. 1985), and forest productivity may increase bird species richness (Cody 1981, Böhm \& Kalko 2009).

Second, the amount and nature of forest edges drive bird community distribution. It has been shown that the amount of edges, subject to higher predation and parasitism, could reduce overall avian biodiversity in forest patches and strongly decrease abundance of specific functional groups preferring forest core (Herkert 1994, Deng \& Gao 2005, Ludwig et al. 2012). There may, however, exist some species preferring the edge, mainly depending on their diet (Kroodsma 1984, McCollin 1998, Martinez-Morales 2005). Overall, the role of edges has been importantly debated in ecology and if their negative impact of avian biodiversity has been recognized, a consensus assessed that edge effects strongly depend on the matrix surrounding the forest patch (Donovan et al. 1997). Noteworthy, the contrast between forest resources and landscape resources (Ries \& Sisk 2004) and the specific interactions between forest species and openfield species (Fagan et al. 1999) are important drivers of edge effect on bird communities.

We observe very different responses of bird communities to the previously-listed habitat factors according to life history traits of bird communities (Lynch \& Whigham 1984, Estades \& Temple 1999, Hansbauer et al. 2010, Gharehaghaji et al. 2012). Life history traits illustrate 
ecological strategy of species to respond to biotic and abiotic conditions, and permit a mechanistic understanding of the relationships between environmental factors and species distribution (Caprio et al. 2008). Clearly, the migratory status - resident, short and longdistance migrant - is an important trait of bird species, which can explain spatial distribution patterns of bird communities (Lynch \& Whigham 1984, Flather \& Sauer 1996, Korňan et al. 2013). Resident and migratory species have indeed different periods of presence in forest patches and thus different temporal dynamics, which lead to different spatial distributions and to seasonal variation in spatial distributions (Griffis-Kyle \& Beier 2005, Böhm \& Kalko 2009).

Most studies on breeding bird distribution in wooded areas focused on landscape or regional scale. At these scales, inter-patch comparisons (size, shape, composition) were designed to explain the variability of bird communities between patches. However, efficient conservation practices often occur at local scale, which is the scale on which management projects are the more easily carried out. Studies looking for mechanisms driving bird distribution at intrapatch scale are scanty (Proença et al. 2010, Albanese \& Davis 2015, Isotti et al. 2015). Furthermore, few studies considered the temporal dynamics depending on the migratory status of species, despite this status was often studied at larger scales. In this study, we proposed to analyse within a same forest patch the relationships between bird species distribution and environmental variables (habitat characteristics) in connection with bird migratory status and intra-season dynamics. Based on previously published work, we addressed the following questions: (i) Do environmental variables explain the distribution of bird species? (ii) Do the distribution patterns depend on the migratory status of species? (iii) Do the distribution patterns vary within the breeding season? We used the point count method to sample the whole bird community of the forest patch of Corbière (Britanny, France), during three years, and using a regular seasonal sampling procedure. We collected a full set of 
relevant environmental variables and tested relationships between bird community and environmental variables, at different times of the breeding season and depending on the migratory status of species.

\section{MATERIALS AND METHODS}

\section{Study area}

The study was carried out in the forest patch of Corbière, located 15 kilometers east of the city of Rennes, Brittany, France ( $\left.48^{\circ} 14^{\prime} \mathrm{N},-^{\circ} 39^{\prime} \mathrm{W}\right)$ and extending 740 hectares (Figure 1). The study area is the property of "Conseil Départemental d'Ille-et-Vilaine" who issued permission for field surveys. This study involved protected species (passerine community) but was only based on audiovisual observations and did not require any official authorization nor ethic committee statements. The forest patch is surrounded by a typical Breton agricultural landscape, which has undergone significant land reparcelling but retains a high degree of heterogeneity. It is a mixed temperate forest mainly composed of deciduous trees belonging principally to Quercus petraea and Quercus pedunculata series. There is a wide range of ecological conditions, especially related to local topography, forest stands and local management - management depends on the owners of the forest stands and is, overall, few intensive.

\section{Composition and abundance of bird community}

The study focused on the forest breeding bird community during the nesting period extending from April to June. The sampling period was in accordance with recommandations of Ralph et al. (1995). It involved all potentially breeding bird species in the forest patch so it was mainly based on the community of passerines (see Appendix 1) with mainly understory nesters. Data were collected by the method of point counts (e.g. Holmes et al. 1986). A grid with a mesh size of $500 \mathrm{~m}$ was positioned on the forest, and 29 bird point counts were 
regularly distributed on the mesh grid to cover the entire forest patch (Figure 1). As one year of study appears insufficient to validate habitat/species relationships (Adamik \& Kornan 2004), we performed the study over 3 years, from 2008 to 2010, with three field sessions at each spring (once per month: April, May, June) to accurately describe the breeding bird community at each point count. During the three annual field sessions, the 29 point counts were sampled within 3 hours from sunrise with a period of listening and observation of 15 minutes at each point, in standardized surveys conditions. All encountered species were recorded, by taking into account only encounters with different individuals, according to the following nomenclature: 1 for songbirds, couples, occupied nests and family groups, and 0.5 for solitary birds seen or heard (songs or calls), to take into account that some birds may be migrating or passing by and did not belong to the local community. We assigned the migratory status of bird species - residents, short-distance migrants and long-distance migrants - using the atlas of Dubois et al. (2008) and “Groupe ornithologique Breton” (2012).

\section{Composition and structure of forest patch}

The Office National des Forêts (ONF) conducted a complete mapping of the forest in the massif of Corbière in 2007, concerning forest stands and habitats: tree species composition, coppice cover, number of dead trees and cavities as well as information on the forest structure with the basal area (reflecting the density and age of the grove, i.e. the sum of the surfaces of each section of tree at 1.30 meter above the ground, in $\mathrm{m}^{2} / \mathrm{ha}$ ). The distribution of stands dominated by deciduous or coniferous trees within the forest patch is shown on Figure 1. A Digital Terrain Model (DTM) was performed to describe patch topography, giving us a quantitative elevation variable at each point count (Figure 1). All information were compiled with a GIS (Geographic Information System, ArcGIS 10 software). Then, we used a buffer of $200 \mathrm{~m}$ radius to quantify the previously-listed environnemental variables around the point counts. We also calculated a distance to the forest edge for each point count. Finally, we 
calculated an heterogeneity index of the tree composition around the point counts; this index was based on the cumulative stand area distribution and was interpreted as the probability that two randomly chosen pixels in the patch were not situated in the same stand (DIVISION index, software Fragstats 4.1., McGarigal et al. 2012). All variables used in analyses are shown in Appendix 2.

\section{Data analysis}

Prior to analyses we center-reduced all data, i.e. transformed variables by subtracting their mean and dividing by their standard deviation, as it ensures regression coefficients are comparable among models. First, we performed a co-inertia analysis (Chessel et al. 2003) to evaluate relationships between distribution of individual bird species and environmental variables. To conduct this analysis, we used a matrix of cumulative maximal abundances, i.e. containing for each point count the sum of the maximal abundances observed for each species during the three years; maximal abundances at each year were obtained using the highest abundance observed along the three annual surveys (April, May, June). Only 35 out of the 54 bird species recorded were considered for this co-inertia analysis, to exclude very rare species that would affect the analysis disproportionally to their abundance (the criteria was species present in less than 3 among the 29 point counts). To perform the co-inertia analysis, a factorial correspondance analysis (COA) was first performed on the matrix of cumulative maximal abundances, then, a principal component analysis (PCA) weighted by the lines of the COA (Chessel et al. 2003) was carried out on the matrix of environmental variablesexcluding redundant environmental variables after prior selection on the matrix of correlations. The co-inertia analysis was finally performed to evaluate covariation between COA and PCA. 
173 Then, we used mixed models (see Zuur et al. 2009) to explain bird community indicators 174 (total abundance, diversity, evenness, abundance of residents, short-distance migrants and 175 long-distance migrants) by environmental variables and month of the breeding season. We used for each month the sum of abundances observed during the three years. Environmental variables were the fixed effects, and month was the random effect - i.e. a 3-level random effect, which is relevant for a random effect (Gelman \& Hill 2007). For each dependent variable, we constructed an initial model containing all the fixed effects and the random effect (fixed effects: distance to edge, coniferous tree cover, deciduous tree cover, coppice cover, elevation, heterogeneity, basal area; random effect: month), and we optimized the model using a backward stepwise selection procedure of explanatory variables, keeping the significant variables only. Random effects were significant when their range of values, i.e. lower/estimate/upper, excluded the zero value. We used the "nlme" package under R software. The best model was selected based on AIC and BIC (Burnham \& Anderson 2002; Chen \& Chen 2008). We tested spatial dependancy of residuals using Moran's I, and all results, despite a slight trend of overdispersion, were non-significant.

Finally, we used multiple ordinary least square regression models to test the relationship between environmental variables and abundances of residents, short-distance migrants and long-distance migrants, at each month of the breeding season. For each dependent variable, we constructed an initial model containing all independent variables, and we optimized the model using a backward stepwise selection procedure of explanatory variables. We tested spatial dependancy of residuals using Moran's I, and all results were clearly non-significant. Here and in previous analyses, distribution of bird community indicators fulfilled normality and homogeneity, we also graphically explored residuals using probability plots and predicted vs residual plots and residuals fulfilled normality and homogeneity. All statistical analyses were performed with R 3.3.1 software (R Development Core Team, 2016). 
Relationship between individual abundance of bird species and environmental variables

200

201

202

203

204

205

206

207

Co-inertia analysis (Figure 2) was highly significant $(P=0.001)$, with a correlation coefficient $\mathrm{RV}=0.50$, and the two first axes supported $62 \%$ of the total variance of the original two matrices. This indicates that several variables explained bird species distribution. These variables were the deciduous or coniferous tree cover (first axis), elevation (first axis), distance to forest edge, basal area, coppice cover and heterogeneity of tree composition (second axis). For instance, we observed that basal area increased abundance of the Eurasian Sparrowhawk (Acni). Meanwhile, the distribution of the Middle Spotted Woodpecker (Deme) was influenced by deciduous trees, like the Short-toed Treecreeper (Cebr) and the Eurasian jay (Gagl). We also observed that when distance to forest edge increased, abundance of migratory species like the Eurasian Golden Oriole (Oror) and the Garden Warbler (Sybo) declined. The Tree Pipit (Antr) and the Common Chiffchaff (Phco) principally followed coniferous tree cover, whereas the Common Firecrest (Reig) responded strongly to the coppice cover and the heterogeneity of tree composition.

\section{Effect of environmental variables on bird community structure}

Various environmental variables significantly explained bird community indicators, and strongly explained abundance of residents, short-distance migrants and long-distance migrants ( $\mathrm{R}^{2}$ ranging from 0.26 to 0.45 , Table 1 ). The month of sampling - random effect - significantly influenced total abundance of bird community as well as abundance of residents and longdistance migrants. This indicates, across the entire forest patch, intra-month and inter-month differences in total abundance of bird community and abundance of residents and longdistance migrants. Distance to edge decreased total abundance and diversity of bird community, as well as abundance of short-distance migrants. Deciduous tree cover increased 
total abundance and diversity of bird community. Elevation decreased evenness of bird community, and was also the variable that discriminated the most bird abundances depending on migratory status: elevation decreased abundance of residents, while it did not change abundance of short-distance migrants, and increased abundance of long-distance migrants (Fig. 3). Also, basal area decreased abundance of short-distance migrants. Finally, coppice cover decreased abundance and diversity of bird community, and decreased abundance of short-distance migrants. Overall, we observed that abundances of residents, short-distance migrants and long-distance migrants were differently related to environmental variables.

Distribution patterns of residents, short and long-distance migrants along the breeding season

Within the three months of the breeding season, environmental variables well explained abundances of residents, short-distance migrants and long-distance migrants ( $\mathrm{R}^{2}$ ranging from 0.10 to 0.38 , Table 2). The distribution pattern of short-distance migrants was quite the same along the breeding season: for all months of the season, abundance of short-distance migrants decreased with distance to edge and coppice cover (Table 2, Figure 4). Meanwhile, abundance of residents and long-distance migrants showed different distribution patterns along the breeding season (Table 2, Figure 4). From graphical illustrations in Figure 3, we learned more from the random effect of the month we observed in the mixed models, since we observed that abundances of residents were higher at the two first months of the breeding season (April and May), while abundances of long-distance migrants were higher at the two last months of the breeding season (May and June). Abundances of short-distance migrants remained quite the same along the entire breeding season, consistently with the non-significance of the random effect of the month in the mixed model (see Tab. 1). Overall, we observed that three of the six variables influencing abundance of both residents and short-distance migrants within the breeding season, acted with the same sign on these abundances (distance to edge, 
deciduous tree cover, coppice cover). Consequently, at the middle of the breeding season (May), residents and short-distance migrants displayed very similar responses to environmental variables. On the other hand, three of the six variables influencing longdistance migrants within the breeding season acted with an opposite sign on abundance of residents or short-distance migrants (distance to edge, elevation, heterogeneity)

\section{DISCUSSION}

\section{Environmental variables drove bird species distribution}

We showed that bird species distribution strongly depended on environmental variables, which were coniferous or deciduous tree cover, distance to forest edge, elevation and basal area. Our results show that at intra-patch scale, distribution patterns can be deterministic and not stochastic, like observed in some studies (Renner et al. 2014). Some species had a clear preference for high zones (European Turtle Dove) or low zones (Middle-Spotted Woodpecker), coniferous zones (Tree Pipit, Crested Tit) or deciduous zones (Shy Jay, Shorttoed Treecreeper), forest edges (Eurasian Golden Oriole, Garden Warbler) or forest core (Great-Spotted Woodpecker, Goldcrest). In contrast, other generalist species such as the Common Chaffinch or European Robin were present and equally abundant in all point counts. Overall, these relationships probably resulted from habitat selection of bird species, which depended on the precise ecological traits of each species (foraging, use of strata, nesting, migration). Our results are hence consistent with studies showing, for instance, an effect of edge (Kroodsma 1984, Ludwig et al. 2012) or composition of the forest stand (Patterson \& Best 1996, Castaño-Villa 2014) on individual bird species distribution. Finally, we observed that variables driving distribution patterns at intra-patch scale may be similar to variables acting at regional scale (Korňan et al. 2013) but may act in very different ways on bird species distribution. 
272 We also observed that indicators of bird community structure were related to environmental

273 variables. Specifically, we showed that elevation decreased evenness of bird community,

274 indicating high zones harbored more rare species. A consistent result was found in a forest

275 mosaic in northern Europe by Luoto et al. (2004), where bird species richness was greater in

276 forests with steep topography. This result is also consistent with general theories in ecology

277 assessing that a tridimensional habitat improves biodiversity, by improving the number of

278 available niches, and consistent with studies on altudinal gradient assessing an increase of

279 species richness with slight elevation (Loiselle \& Blake 1991, Grytnes \& Vetaas 2002).

280 Moreover, deciduous tree cover increased abundance and diversity of bird community. We

281 might propose that deciduous zones provided a range of habitats and resources which was

282 larger than that of coniferous zones. Also, coppice cover decreased abundance and diversity

283 of bird community, suggesting birds preferred clear zones with sparse understory to nest.

284 Finally, distance to edge decreased abundance and diversity of bird community. This last

285 result indicates that bird community benefited from the proximity of forest edge, and hence

286 indicates a positive edge effect. This result challenges the frequent observations of negative

287 edge effects at the landscape scale (Rodewald 2002, Batary \& Baldi 2004, Deng \& Gao 2005,

288 Ludwig et al. 2012). From other studies (Penhollow \& Stauffer 2000, Bulluck \& Rowe 2006,

289 Vetter et al. 2013), we might suggest that the forest edge, surrounded by an agricultural

290 landscape which conserves a high degree of heterogeneity, was a zone of high ecological

291 diversity and biotic interactions rather than a zone of high perturbation.

Spatial partitioning between resident and migratory birds

293 Our results clearly showed a spatial partitioning between resident and migratory birds. Short294 distance migrants were located mainly close to the forest edge, in sites with sparse understory 
and low tree density. Residents preferred low sites, whereas long-distance migrants preferred high sites. Local environmental factors play therefore an important role for habitat selection in bird species depending on the migratory status of species. These results are new because no study, to our knowledge, showed an influence of phenology on habitat selection at intra-patch scale. The positive edge effect observed on abundance of short-distance migrants contradicts previous studies at the regional scale which found that fragmentation, resulting in increased forest edges, decreased migratory species richness (Robinson et al. 1995). Meanwhile, a modeling approach employed by Goldstein et al. (2003) concluded that maximum richness of migratory species was achieved with an intermediate level of fragmentation, and Gates \& Giffen (1991) showed the concentration of migratory birds at edges adjacent to ecotones (riparian zones). Goetz et al. (2010) also demonstrated the importance of structure and canopy height to explain migratory species richness. Overall, we hence note that numerous factors could explain the positive edge effect we found for short-distance migrants, and it would be an interesting perspective to study whether the matrix surrounding the forest patch may drive this edge effect. It would be also interesting to test whether differential habitat selection between migratory and resident birds could be used as a proxy for evaluating impacts of habitat fragmentation (Fahrig 1997, Fahrig 2003, Ribeiro et al. 2009, Lindenmayer \& Fischer 2013).

\section{Temporal dynamics of resident and migratory birds}

We found that the relationships between environmental variables and abundance of residents and long-distance migrants changed along the breeding season, while relationships between environmental variables and short-distance migrants persisted. Moreover, abundance of shortdistance migrants was stable during the breeding season, while abundance of residents decreased at the last month of the breeding season and abundance of long-distance migrants increased from the second month. Thus, these results suggest a temporal dynamics of resident 
and migrant bird distribution, which could explain their spatial partitioning at the scale of the entire breeding season as well as the spatial structure of entire bird community. Long-distance migrants arrived indeed in the forest patch later than residents and short-distance migrants, in particular because presence of residents within the forest patch could be quite continuous during the year. Overall, distribution patterns of residents were closer to distribution patterns of short-distance migrants than those of long-distance migrants. Therefore, long-distance migrants might not find the same availability of habitats, and nested in zones less occupied by residents and short-distance migrants. An opposite result was found at inter-patch scale by Mönkkönen et al. (1990) and Thomson et al. (2003), who found the existence of an heterospecific attraction resulting in migratory species choosing habitat patches with many resident species, whose presence is interpreted as a signal of high habitat quality. Overall, if it had already been shown that habitat preferences of bird communities could vary seasonally between breeding season in spring and the beginning of autumnal migration (Murcia 1995, Griffis-Kyle \& Beier 2005, Böhm \& Kalko 2009, Keller et al. 2009, Naoe et al. 2011), no study had yet taken into account intra-season dynamics of bird distribution and the role of functional groups of migratory and resident birds in this dynamics. Thus, our results are novel and highlight the importance of accounting for spatio-temporal distribution patterns at fine scale.

\section{CONCLUSION}

Our study showed at intra-patch scale that environmental variables (distance to edge, deciduous tree cover, elevation, coppice cover) drove individual bird species distribution as well as bird community indicators (abundance, diversity, evenness). Moreover, abundances of residents, short-distance migrants and long-distance migrants were differently related to environmental variables, in particular in regard to distance to forest edge, tree density, coppice cover and elevation. We also found that spatial distribution of bird species changed 
during the breeding season, depending on the migratory status of species. Specifically, we observed that, within the breeding season, distribution patterns of short-distance migrants were closer to distribution patterns of residents than to distribution patterns of long-distance migrants. Overall, long-distance migrants arrived later than residents and short-distance migrants in the breeding season, and it might explain the spatial partioning we observed between resident and migrant birds as well as the structure of the entire bird community: longdistance migrants might not find the same availability of high quality habitats, and might be forced to fall back on still available or low quality ones. These results show the importance of approach to assessing the influence of beech forest structure on bird communities. Forest
Balestrieri R, Basile M, Posillico M, Altea T, De Cinti B, Matteucci G (2015) A guild-based

taking into account functional traits of bird species, especially migratory status, and intraseason temporal dynamics to study and understand the distribution patterns of bird communities. Such results may have implications for forest management, to optimize species assemblages and hence the conservation of avian biodiversity in temperate forest environments.

\section{REFERENCES}

Adamík P, Kornan M (2004) Foraging ecology of two bark foraging passerine birds in an oldgrowth temperate forest. Ornis Fennica 81:13-22.

Albanese G, Davis CA (2015) Characteristics within and around stopover wetlands used by migratory shorebirds: Is the neighborhood important? The Condor 117:328-340.

Ecology and Management 356:216-223. 
Batary P, Baldi A (2004) Evidence of an edge effect on avian nest success. Conservation Biology 18:389-400.

369

Berg $\AA$ (1997) Diversity and abundance of birds in relation to forest fragmentation, habitat quality and heterogeneity. Bird Study 44:355-366.

Böhm SM, Kalko EK (2009) Patterns of resource use in an assemblage of birds in the canopy of a temperate alluvial forest. Journal of Ornithology 150:799-814.

Both C, Visser ME (2001) Adjustment to climate change is constrained by arrival date in a long-distance migrant bird. Nature 411:296-298.

Bulluck JF, Rowe MP (2006) The use of southern Appalachian wetlands by breeding birds, with a focus on Neotropical migratory species. The Wilson Journal of Ornithology 118:399410.

Burnham KP, Anderson DR (2002) Model selection and multimodel inference: a practical information-theoretic approach. Springer-Verlag. USA, 515p.

Canterbury GE, Martin TE, Petit DR, Petit LJ, Bradford DF (2000) Bird communities and habitat as ecological indicators of forest condition in regional monitoring. Conservation Biology 14:544-558.

Caprio E, Ellena I, Rolando A (2009) Assessing habitat/landscape predictors of bird diversity in managed deciduous forests: a seasonal and guild-based approach. Biodiversity and conservation 18:1287-1303.

Castaño-Villa GJ, Ramos-Valencia SA, Fontúrbel FE (2014) Fine-scale habitat structure complexity determines insectivorous bird diversity in a tropical forest. Acta Oecologica 61:19-23. 
Chen J, Chen Z (2008) Extended Bayesian information criteria for model selection with large model spaces. Biometrika 95:759-771.

Chessel D, Thioulouse J, Dray S (2003) Co-inertia analysis and the linking of ecological data tables. Ecology 84:3078-3089.

Cody ML (1981) Habitat selection in birds: the roles of vegetation structure, competitors, and productivity. BioScience 31:107-113.

Deng WH, Gao W (2005) Edge effects on nesting success of cavity-nesting birds in fragmented forests. Biological Conservation 126:363-370.

Devictor V, Godet L, Julliard R, Couvet D, Jiguet F (2007) Can common species benefit from protected areas? Biological Conservation 139:29-36.

Donovan TM, Jones PW, Annand EM, Thompson FR (1997) Variation in local-scale edge effects: mechanisms and landscape context. Ecology 78:2064-2075.

Dubois PJ, Le Maréchal P, Olioso G, Yésou P (2008) Nouvel inventaire des oiseaux de France. Delachaux et Niestlé. Slovenia, 559p.

Estades CF, Temple SA (1999) Deciduous-forest bird communities in a fragmented landscape dominated by exotic pine plantations. Ecological Applications 9:573-585.

Fagan WF, Cantrell RS, Cosner C (1999) How habitat edges change species interactions. The American Naturalist 153:165-182.

Fahrig L (1997) Relative effects of habitat loss and fragmentation on population extinction. The Journal of Wildlife Management 61:603-610.

Fahrig L (2003) Effects of habitat fragmentation on biodiversity. Annual Review of Ecology, Evolution, and Systematics 64:487-515. 
411 Flather CH, Sauer JR (1996) Using landscape ecology to test hypotheses about large-scale

412 abundance patterns in migratory birds. Ecology 77:28-35.

413 Freemark KE, Merriam HG (1986) Importance of area and habitat heterogeneity to bird 414 assemblages in temperate forest fragments. Biological Conservation 36:115-141.

415 Gates JE, Giffen NR (1991) Neotropical migrant birds and edge effects at a forest-stream 416 ecotone. Wilson Bulletin 103:204-217.

417 Gelman A, Hill J (2007) Data analysis using regression and multilevelhierarchical models. 418 New Cambridge University Press. York, NY, USA, 625p.

419 Gharehaghaji M, Shabani AA, Feghhi J, Danehkar A, Kaboli M, Ashrafi S (2012) Effects of 420 landscape context on bird species abundance of tree fall gaps in a temperate deciduous forest 421 of Northern Iran. Forest Ecology and Management 267:182-189.

422 Goetz SJ, Steinberg D, Dubayah R, Blair B (2007). Laser remote sensing of canopy habitat 423 heterogeneity as a predictor of bird species richness in an eastern temperate forest, USA. 424 Remote Sensing of Environment 108:254-263.

425 Goetz SJ, Steinberg D, Betts MG, Holmes RT, Doran PJ, Dubayah R, Hofton M (2010) Lidar 426 remote sensing variables predict breeding habitat of a Neotropical migrant bird. Ecology 427 91:1569-1576.

428 Goldstein MI, Corson MS, Lacher Jr TE, Grant WE (2003) Managed forests and migratory 429 bird populations: evaluating spatial configurations through simulation. Ecological Modelling $430 \quad 162: 155-175$. 
Gregory RD, Vorisek P, Van Strien A, Gmelig Meyling AW, Jiguet F, Fornasari L, Reif J, Chylarecki P, Burfield IJ (2007) Population trends of widespread woodland birds in Europe. Ibis 149:78-97.

Griffis-Kyle KL, Beier P (2005) Migratory strategy and seasonal patterns of bird diversity in relation to forest habitat. The American Midland Naturalist 153:436-443.

Groupe ornithologique breton (2012). Atlas des oiseaux nicheurs de Bretagne. Delachaux et Niestlé. France, 512p.

Grytnes JA, Vetaas OR (2002) Species richness and altitude: a comparison between null models and interpolated plant species richness along the Himalayan altitudinal gradient, Nepal. The American Naturalist 159:294-304.

Hansbauer MM, Storch I, Knauer F, Pilz S, Küchenhoff H, Végvári Z, Pimentel RG, Metzger JP (2010) Landscape perception by forest understory birds in the Atlantic Rainforest: blackand-white versus shades of grey. Landscape Ecology 25:407-417.

Herkert JR (1994) The effects of habitat fragmentation on midwestern grassland bird communities. Ecological Applications 4:461-471.

Holmes RT, Sherry TW, Sturges FW (1986) Bird community dynamics in a temperate deciduous forest: long-term trends at Hubbard Brook. Ecological Monographs 56:201-220.

Isotti R, Battisti C, Luiselli L (2015) Seasonal and habitat-related changes in bird assemblage structure: applying a diversity/dominance approach to Mediterranean forests and wetlands. Israel Journal of Ecology \& Evolution 61:28-36.

James FC, Wamer NO (1982) Relationships between temperate forest bird communities and vegetation structure. Ecology 63:159-171. 
453

454

455

456

457

458

459

460

461

462

463

464

465

466

467

468

469

470

471 472 P (2012) Landscape-moderated bird nest predation in hedges and forest edges. Acta

473 Oecologica 45:50-56.

Jenni L, Kéry M (2003) Timing of autumn bird migration under climate change: advances in long-distance migrants, delays in short-distance migrants. Proceedings of the Royal Society of London Series B: Biological Sciences 270:1467-1471.

Jiguet F, Devictor V, Julliard R, Couvet D, Lee A (2007) Functional homogenization effect of urbanization on bird communities. Conservation Biology 21:741-751.

Julliard R, Jiguet F, Couvet D (2003) Common birds facing global changes: what makes a species at risk? Global Change Biology 10:148-154

Keller GS, Ross BD, Klute DS, Yahner RH (2009) Temporal changes in migratory bird use of edges during spring and fall seasons in Pennsylvania. Northeastern Naturalist 16:535-552.

Korňan M, Holmes RT, Recher HF, Adamik P, Kropil R (2013) Convergence in foraging guild structure of forest breeding bird assemblages across three continents is related to habitat structure and foraging opportunities. Community Ecology 14:89-100.

Kroodsma RL (1984). Effect of edge on breeding forest bird species. The Wilson Bulletin 96:426-436.

Lindenmayer DB, Fischer J (2013) Habitat fragmentation and landscape change: an ecological and conservation synthesis. Island Press. England, 352p.

Loiselle BA, Blake JG (1991) Temporal variation in birds and fruits along an elevational gradient in Costa Rica. Ecology 72:180-193.

Ludwig M, Schlinkert H, Holzschuh A, Fischer C, Scherber C, Trnka A, Tscharntke T, Batary Oecologica 45:50-56. 
Luoto M, Virkkala R, Heikkinen RK, Rainio K (2004) Predicting bird species richness using remote sensing in boreal agricultural-forest mosaics. Ecological Applications 14:1946-1962.

Lynch JF, Whigham DF (1984) Effects of forest fragmentation on breeding bird communities in Maryland, USA. Biological Conservation 28:287-324.

Martinez-Morales MA (2005) Landscape patterns influencing bird assemblages in a fragmented Neotropical cloud forest. Biological Conservation 121:117-126.

McCollin D (1998) Forest edges and habitat selection in birds: a functional approach. Ecography 21:247-260.

McGarigal K, Cushman SA, Ene E (2012) FRAGSTATS v4: Spatial Pattern Analysis Program for Categorical and Continuous Maps. Computer software program produced by the authors at the University of Massachusetts, Amherst.

Mönkkönen M, Helle P, Soppela K (1990) Numerical and behavioural responses of migrant passerines to experimental manipulation of resident tits (Parus spp.): heterospecific attraction in northern breeding bird communites? Oecologia 85:218-225.

Murcia C (1995) Edge effects in fragmented forests: implications for conservation. Trends in Ecology \& Evolution 10:58-62.

Naoe S, Sakai S, Sawa A, Masaki T (2011) Seasonal difference in the effects of fragmentation on seed dispersal by birds in Japanese temperate forests. Ecological Research 26:301-309.

Patterson MP, Best LB (1996) Bird abundance and nesting success in Iowa CRP fields: The importance of vegetation structure and composition. American Midland Naturalist 135:153167. 
Penhollow ME, Stauffer F (2000) Large-scale habitat relationships of Neotropical migratory birds in Virginia. The Journal of Wildlife Management 64:362-373.

Petit DR, Petit KE, Grubb Jr TC (1985) On atmospheric moisture as a factor influencing distribution of breeding birds in temperate deciduous forest. The Wilson Bulletin 97:88-96.

Poulsen BO (2002) Avian richness and abundance in temperate Danish forests: tree variables important to birds and their conservation. Biodiversity and Conservation 11:1551-1566.

Proença VM, Pereira HM, Guilherme J, Vicente L (2010) Plant and bird diversity in natural forests and in native and exotic plantations in NW Portugal. Acta Oecologica 36:219-226.

R Development Core Team (2016) R: A language and environment for statistical computing. R Foundation for Statistical Computing. Vienna, Austria.

Ralph CJ, Droege S, Sauer JR (1995) Managing and monitoring birds using point counts: standards and applications. USDA Forest Service Gen. Tech. Rep. PSW-GTR-149 161-168.

Raymond CM, Fazey I, Reed MS, Stringer LC, Robinson GM, Evely AC (2010) Integrating local and scientific knowledge for environmental management. Journal of environmental management, 91:1766-1777.

Renner SC, Gossner MM, Kahl T, Kalko EK, Weisser WW, Fischer M, Allan E (2014) Temporal changes in randomness of bird communities across Central Europe. PLoS One 9 doi:10.1371/journal.pone.0112347.

Ribeiro MC, Metzger JP, Martensen AC, Ponzoni FJ, Hirota MM (2009) The Brazilian Atlantic Forest: How much is left, and how is the remaining forest distributed? Implications for conservation. Biological Conservation 142:1141-1153.

Ries L, Sisk TD (2004) A predictive model of edge effects. Ecology 85:2917-2926. 
Robinson SK, Thompson RF, Donovan MT, Whitehead DR, Faaborg J (1995) Regional forest fragmentation and the nesting success of migratory birds. Science 267:93-102.

Rodewald AD (2002) Nest predation in forested regions: landscape and edge effects. The Journal of Wildlife Management 66:634-640.

Sanderson FJ, Donald PF, Pain DJ, Burfield IJ, Van Bommel FP (2006) Long-term population declines in Afro-Palearctic migrant birds. Biological Conservation 131:93-105.

Thomson RL, Forsman JT, Mönkkönen M (2003) Positive interactions between migrant and resident birds: testing the heterospecific attraction hypothesis. Oecologia 134:431-438.

Tryjanowski P, Kuźniak S, Sparks TH (2005) What affects the magnitude of change in first arrival dates of migrant birds? Journal of Ornithology 146:200-205.

Vetter D, Rücker G, Storch I (2013) A meta-analysis of tropical edge effects on bird nest predation risk: edge effect in avian nest predation. Biological Conservation 159:382-395.

Zuur AF, Ieno EN, Walker NJ, Saveliev AA, Smith GM (2009) Mixed effects models and extensions in ecology with R. Springer. USA, 574p. 
538

539

540

541 
543 Table 1. Environmental variables influenced bird community indicators. Summary of the best

544 mixed models explaining each indicator of bird community by environmental variables. The

545 effect of each significant fixed variables is indicated with its standardized regression

546 coefficient and significance (*: $\mathrm{P}<0.05$; **: $\mathrm{P}<0.01$; ***: $\mathrm{P}<0.001)$ and the random effect is

547 also indicated when significant (see Methods for model construction). $\mathrm{N}$ is the whole sample

548 size and Adj- $\mathrm{R}^{2}$ is the adjusted R-squared. Diversity is evaluated by the Shannon index.

\begin{tabular}{|c|c|c|c|c|c|c|c|c|c|}
\hline \multirow[b]{2}{*}{$\begin{array}{l}\text { Bird community } \\
\text { indicator }\end{array}$} & \multicolumn{7}{|c|}{ Effect of environmental variables } & \multirow[b]{2}{*}{$\mathrm{N}$} & \multirow[b]{2}{*}{ Adj- $R^{2}$} \\
\hline & & & $e^{e^{v^{8}}}$ & & $\rho^{0 p}$ & $-\frac{\text { Random e }}{\text { Inter: }}$ & $-\frac{\text { Intra: }}{\text { loct (month) }}-$ & & \\
\hline Abundance & $-0.30^{*}$ & $0.32^{*}$ & & & $-0.32 * *$ & $0.1 / 0.4 / 1.2$ & $0.8 / 0.9 / 1.1$ & 87 & 0.21 \\
\hline Diversity & $-0.38 * *$ & $0.36 * *$ & & & $-0.35 * *$ & & & 87 & 0.12 \\
\hline Evenness & & & $-0.23 *$ & & & & & 87 & 0.05 \\
\hline Residents & & & $-0.42 * * *$ & & & $0.1 / 0.3 / 1.1$ & $0.7 / 0.9 / 1.0$ & 87 & 0.27 \\
\hline Short-distance migrants & $-0.46 * * *$ & & & $-0.42^{* * *}$ & $-0.47^{* * *}$ & & & 87 & 0.26 \\
\hline Long-distance migrants & & & $0.32 * * *$ & & & $0.2 / 0.6 / 1.8$ & $0.7 / 0.8 / 0.9$ & 87 & 0.45 \\
\hline
\end{tabular}


Table 2. Relationships between environmental variables and short-distance migrants persisted

561 along the breeding season, while relationships between environmental variables and 562 abundances of residents and long-distance migrants changed. Summary of the best multiple

563 linear models explaining abundances of residents, short-distance migrants and long-distance 564 migrants by environmental variables, at the three months of the breeding season. The effect of 565 each significant variables is indicated with its standardized regression coefficient and 566 significance (*: $\mathrm{P}<0.05$; **: $\mathrm{P}<0.01 ; * * *$ : $\mathrm{P}<0.001)$. Other model parameters are the degree of 567 freedom (Df), the F statistic (F), the $P$-value $(P)$, and the adjusted R-squared (Adj- $\left.\mathrm{R}^{2}\right)$.

\begin{tabular}{|c|c|c|c|c|c|c|c|c|c|c|c|c|}
\hline \multirow[b]{2}{*}{ Abundance of } & \multirow[b]{2}{*}{ Month } & \multicolumn{7}{|c|}{ Effect of environmental variables } & \multirow[b]{2}{*}{ Df } & \multirow[b]{2}{*}{$\mathrm{F}$} & \multirow[b]{2}{*}{$P$} & \multirow[b]{2}{*}{ Adj- $R^{2}$} \\
\hline & & $e^{x^{0}}$ & & & & & & & & & & \\
\hline \multirow{3}{*}{ Residents } & April & & & & $-0.59 * * *$ & & & & 27 & 14.6 & $<0.001$ & 0.33 \\
\hline & May & $-0.37 *$ & & $0.86 * * *$ & & & & $-0.44^{*}$ & 25 & 6.7 & $<0.001$ & 0.38 \\
\hline & June & & & & & & $0.37^{*}$ & & 27 & 4.2 & $<0.05$ & 0.10 \\
\hline \multirow{3}{*}{$\begin{array}{c}\text { Short-distance } \\
\text { migrants }\end{array}$} & April & $-0.57^{* *}$ & & & & & $-0.60 * *$ & $-0.50 *$ & 25 & 6.0 & $<0.01$ & 0.35 \\
\hline & May & $-0.89 * *$ & & $0.54^{*}$ & & $-0.65^{*}$ & & $-0.37 *$ & 24 & 3.5 & $<0.05$ & 0.26 \\
\hline & June & $-0.42 *$ & & & & & $-0.38 *$ & $-0.57^{* *}$ & 25 & 3.4 & $<0.05$ & 0.21 \\
\hline \multirow{3}{*}{$\begin{array}{l}\text { Long-distance } \\
\text { migrants }\end{array}$} & April & $0.61^{*}$ & $0.41^{*}$ & & & $0.70^{*}$ & & & 25 & 2.6 & $<0.05$ & 0.15 \\
\hline & May & & & & $0.42^{*}$ & & & & 27 & 5.9 & $<0.05$ & 0.15 \\
\hline & June & & & & $0.68 * * *$ & $0.30^{*}$ & & $-0.43^{*}$ & 25 & 6.4 & $<0.001$ & 0.37 \\
\hline
\end{tabular}


577

578

579

580

581

582

583

584

585

586

587

588

589

590

591

592

593

594

595

596

597

598

599

Figure 1. Localisation of the study area and positions of the 29 bird point counts $(500 \mathrm{~m}$ square grid), with (a): Elevation data and (b): Areas with dominant deciduous or coniferous tree communities.

Figure 2. Environmental variables drove individual abundance of bird species. PC1/PC2 coinertia plane with projection of species (italics) and environmental variables (bold). Correlation coefficient $=0.50, P=0.001$ and total inertia=61.7\%. Species codes: Frco: Fringilla coelebs; Erru: Erithacus rubecula; Trtr: Troglodytes troglodytes; Tume: Turdus merula; Phco: Phylloscopus collybita; Copa: Columba palumbus; Syat: Sylvia atricapilla; Sieu: Sitta europaea; Cebr: Certhia brachydactyla; Tuph: Turdus philomelos; Paca: Parus caeruleus; Tuvi: Turdus viscivorus; Dema: Dendrocopos major; Cocor: Corvus corone; Pama: Parus major; Cuca: Cuculus canorus; Oror: Oriolus oriolus; Phsi: Phylloscopus sibilatrix; Gagl: Garrulus glandarius; Papa: Parus palustris; Sttu: Streptopelia turtur; Rere: Regulus regulus; Antr: Anthus trivialis; Pivi: Picus viridis; Phph: Phoenicurus phoenicurus; Sybo: Sylvia borin; Prmo: Prunella modularis; Reig: Regulus ignicapilla; Deme: Dendrocopos medius; Stvu: Sturnus vulgaris; Drma: Dryocopus martius ; Aeca: Aegithalos caudatus; Pacr: Parus cristatus; Bubu: Buteo buteo; Acni: Accipiter nisus.

Figure 3. Influence of elevation on abundance of resident birds (filled triangles and full lines), short-distance migrant birds (empty points and fine-dashed lines) and long-distance migrant birds (filled points and large-dashed lines), over the entire breeding season. See Table 1 for models.

Figure 4. Influence of distance to edge and coppice cover on abundance of resident birds (filled triangles and full lines), short-distance migrant birds (empty points and fine-dashed lines) and long-distance migrant birds (filled points and large-dashed lines), for the three 


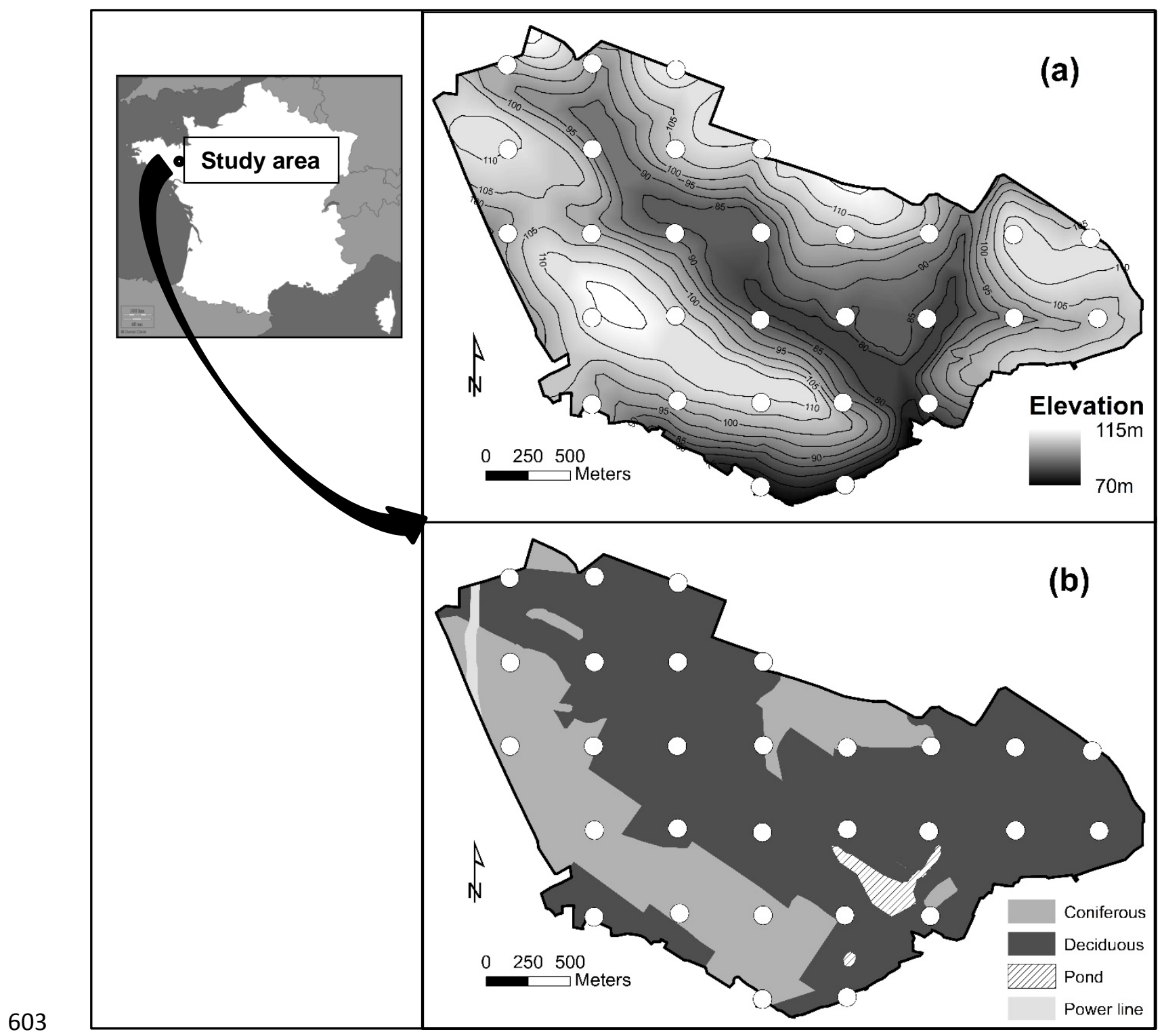

Figure 1. 


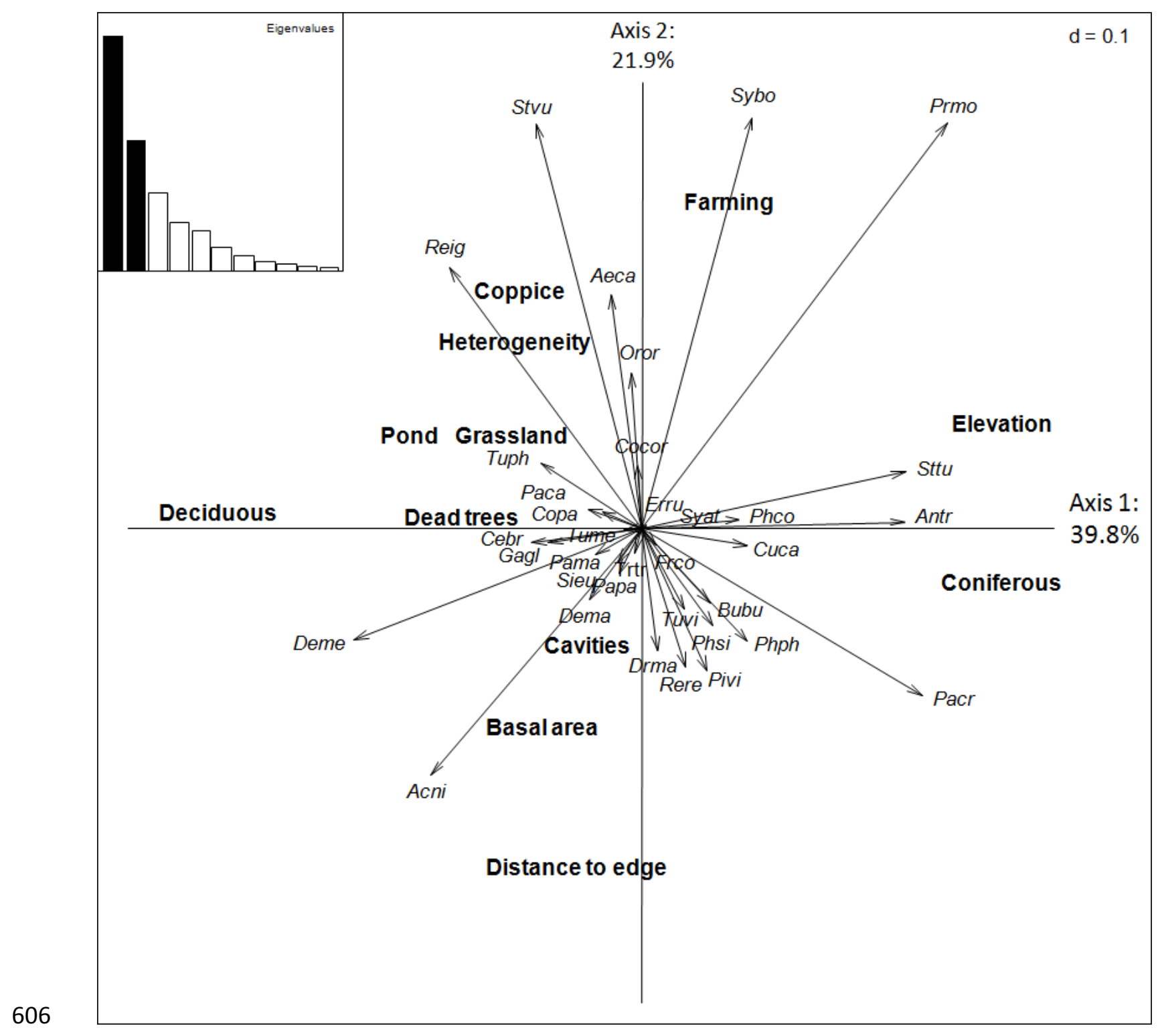

607

Figure 2.

608 


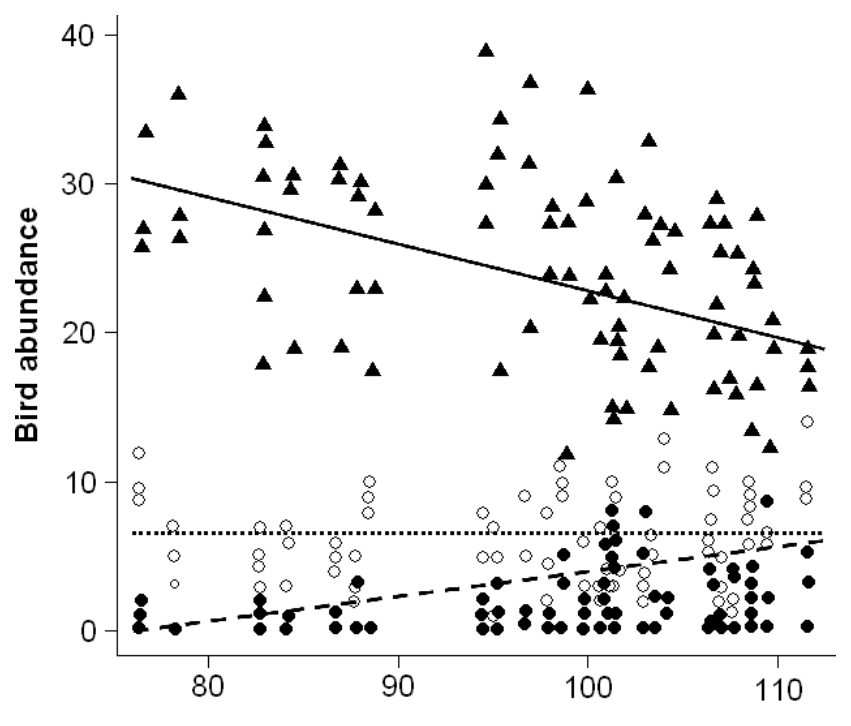

609

Elevation (m)

$610 \quad$ Figure 3.

611

612

613

614

615

616 

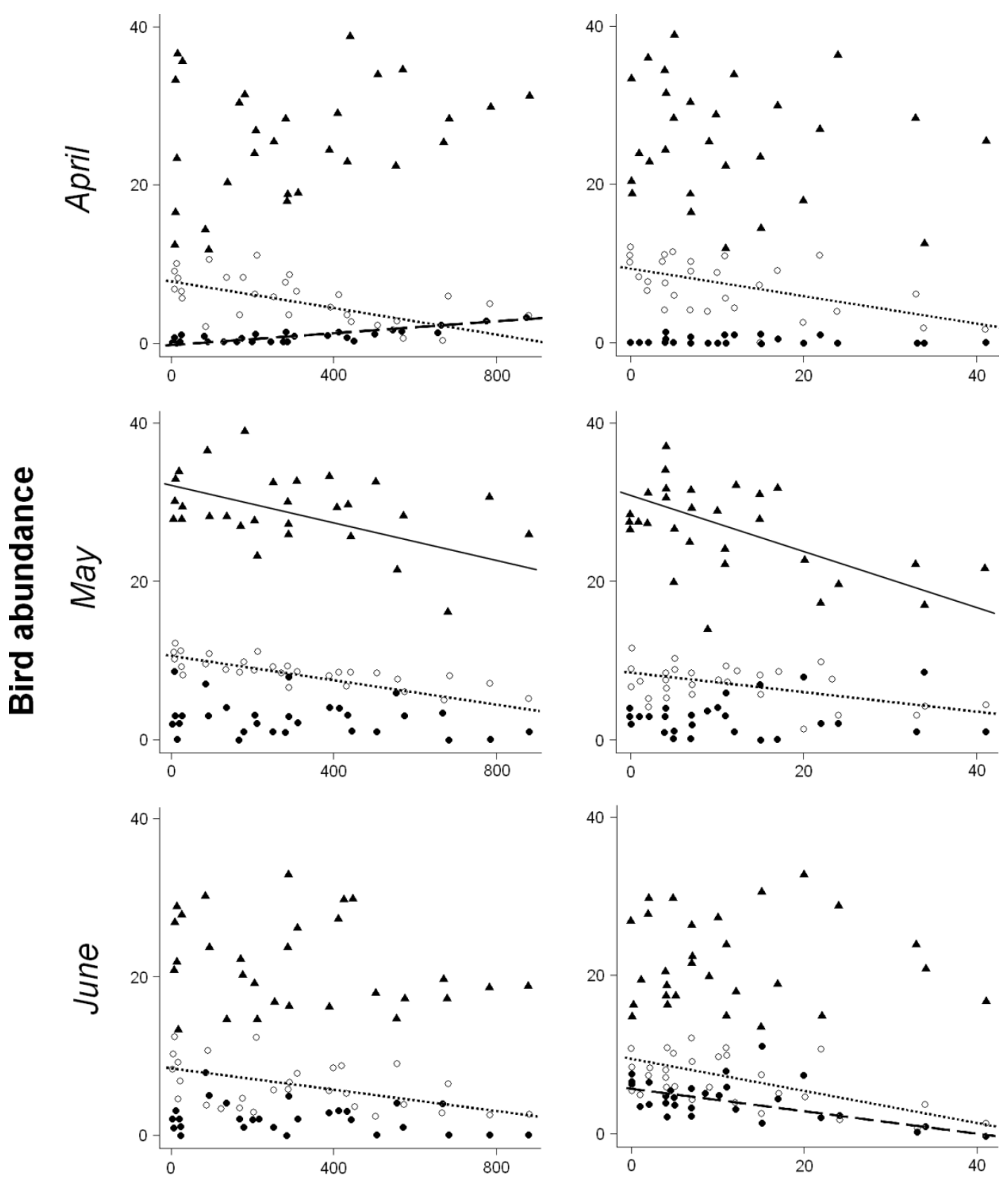

617

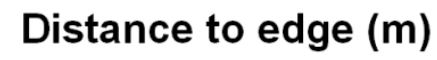

Coppice (\%)

$618 \quad$ Figure 4.

619 